\title{
KONTEKSTUALISASI EKONOMI KREATIF PARTISIPATIF MENUJU KEMANDIRIAN PESANTREN
}

\author{
Darul Ma'arif \\ Institut Agama Islam Riyadlotul Mujahidin (IAIRM) Ngabar Ponorogo \\ Darulmaarif91@gmail.com
}

\begin{abstract}
The development of pesantren in Indonesia clearly coloring the history of Islamic education in Indonesia. In line with the social change due to modernization-industrialization inevitably requires the pesantren to provide adequate reaction or response. The recation of pesantren on changes that occur so far is soft and hard. There is an open da tone that is close. Therefore, the function of Pesantren not only as a center to produce a religious thinker (center of Excellence), as well as to print human resources, but also expected to be an institution that can empower the community (development agents). Seeing its function, pesantren can actually act as an intermediary institution that is expected to be dynamic and catalysts to empower human resources, encourage development in all fields, including in the economic field. As a consequence of community involvement in strengthening the economy among Islamic schools, it has not been touched creatively and seriously in the form of integral and explicit integration by the Pesantren. Tradition itself is not enough to metamorphosed as the values of civil society are civilized, universal and oriented far forward. The purpose of this research is to raise the spirit of Pesantren especially in realizing a postoperative creative economy to be able to sustain the pace of the economy of pesantren and increase the role of community around in the management and development of Islamic boarding.
\end{abstract}

\section{Keywords: Participatory economics, independence of Pesantren}

\begin{abstract}
Abstrak
Petumbuhan dan perkembangan pesantren di Indonesia jelas mewarnai sejarah pendidikan Islam di Indonesia. Sejalan dengan perubahan sosial akibat modernisasi-industrialisasi pasti membutuhkan pesantren untuk memberikan reaksi atau respon yang memadai. Rekasi pesantren terhadap perubahan yang terjadi sejauh ini lembut dan keras. Ada yang terbuka da nada yang dekat. Oleh karena itu, fungsi pesantren tidak hanya sebagai pusat untuk menghasilkan pemikir agama (center of excellence), sebagailembaga yang mencetak sumber daya manusia, tetapi juga diharapkan menjadi lembaga yang dapat memberdayakan masyarakat (agen pembangunan). Melihat fungsinya, pesantren sebenarnya dapat bertindak sebagai lembaga perantara yang diharapkan menjadi dinamis dan katalisator untuk memberdayakan sumber daya manusia, mendorong pembangunan disemua bidang, termasuk di bidang ekonomi. Sebagai konsekuensi dari keterlibatan masyarakat dalam memperkuat ekonomi diantara pesantren, ia belum tersentuh secara kreatif dan serius dalam bentuk integrasi integral dan eksplisit oleh pesantren. Tradisi itu sendiri tidak cukup untuk bermetamorfosis sebagai nilai-nilai masyarakat sipil yang beradab, universal dan berorientasi jauh ke depan. Tujuan dari penelitian ini adalah untuk memunculkan spirit pesantren khususnya dalam mewujudkan ekonomi kreatif pastisipatif untuk dapat menopang laju perekonomian pesantren serta meningkatkan peran masyarakat sekitar dalam pengelolaan dan pengembangan ekonomi pesantren.
\end{abstract}

\section{Kata kunci: ekonomi partisipatif, kemandirian pesantren}

\section{A. Pendahuluan}

Secara umum pesantren diartikan sebagai tempat tinggal para santri. Secara utuh Dhofier juga menjelaskan bahwa pesantren merupakan sebuah lembaga pendidikan keagamaan tradisional Islam untuk mempelajari, memahami, mendalami, menghayati dan mengamalkkan ajaran Islam dengan menekankan pentingnya moral. Pondok pesantren sebagai lembaga pendidikan Islam lebih 
populer di masyarakat Pulau Jawa. ${ }^{1}$ Terdapat kesepakatan di antara ahli sejarah Islam bahwa pendiri pesantren pertama adalah dari kalangan Walisongo sekitar abad $15 \mathrm{M}$. Walisongo adalah pelopor dan pemimpin dakwah Islam yang berhasil merekrut murid untuk kemudian menjalankan dakwah di setiap penjuru negeri. Dalam pandangan orang jawa, Walisongo adalah pemimpin umat yang sangat saleh dan dengan pencerahan spiritual religius mereka, bumi jawa yang tadinya tidak mengenal agama monotheis menjadi bersinar terang. Posisi mereka dalam kehidupan sosio-kultural dan religius di Jawa demikian memikat. Mereka adalah Maulana Malik Ibrahim, Sunan Ampel, Sunan Bonang, Sunan Kalijaga, Sunan Drajat, Sunan Girl, Sunan Kudus, Sunan Muria dan Sunan Gunung Jati. Pertumbuhan dan perkembangan pesantren di Indonesia, jelas telah mewarnai perjalanan sejarah pendidikan Islam di Indonesia. Kendatipun demikian pesantren dengan berbagai kelebihannya, tentunya juga tidak dapat menghindar dari kritik terhadap kekurangannya. Bagaimanapun keadaan pesantren dengan segala kelebihan dan kekurangannya, kita mengakui besarnya arti pesantren dalam perjalanan bangsa Indonesia, khususnya Jawa, dan tidak berlebihan jika pesantren dianggap sebagai bagian historis bangsa Indonesia yang harus dipertahankan.

\section{B. Perkembangan Pesantren}

Dhofier menyebutkan bahwa kehidupan pondok pesantren ditandai dengan kesederhanaan bangunan-bangunan sekitar pesantren, kesederhanaan cara hidup santri, kepatuhan para santri kepada kiainya dan pembelajaran dasar kitab-kitab klasik agama Islam. ${ }^{2}$ Dalam perspektif sejarah, lembaga pendidikan yang pada umumnya berbasis di pedesaan ini menurut Sujoko. P "pesantren telah mengalami perjalanan sejarah yang panjang sejak sekitar abad ke 18, dan gagasan mengenai penelitian pesantren bermula lahir dari seminar tentang Partisipasi Sosial pada bulan September tahun 1971."3 Seiring dengan perjalanan waktu proses modernisasi terjadi hampir pada seluruh aspek kehidupan masyarakat, termasuk modernisasi yang terjadi pada lembaga pendidikan pesantren terutama pesantren tradisional (salafi) yang semakin banyak mengalami pe-rubahan ke arah modern. Modernisasi pesantren terjadi pada aspek fisik dan non fisik.

Hal ini sebagaimana dijelaskan oleh Damopolii bahwa orientasi utama pesantren salafi hanya memberikan layanan dalam kajian agama Islam atau taffaqquh fi al-din kepada santrinya, orientasi ini teralu sempit karena tidak responsif terhadap dinamika masyarakat yang terus bergerak maju. ${ }^{4}$ Dapat dipahami bahwa saat ini banyak dari pesantren salafi yang secara bertahap memberi respon terhadap tuntutan kebutuhan masyarakat. Bentuk respon pesantren terhadap dinamika dan tuntutan kebutuhan masyarakat tersebut di-jelaskan oleh Husni Rahim yang berpendapat bahwa pada akhirnya pesantren tidakS hanya mengajarkan ilmu-ilmu agama saja, tetapi juga mengajarkan ilmuilmu umum. Hal ini terbukti dengan banyaknya pesantren yang menyelenggarakan pendidikan sekolah di-samping pendidikan madrasah ${ }^{5}$

Proses modernisasi yang terjadi di masyarakat membawa dampak terhadap pengaruh orang tua atas pilihan pekerjaan anak. Pada masyarakat tradisional pengaruh orang tua ter-hadap pilihanpilihan pekerjaan anak sangat besar dan lagi pilihan pekerjaan anak masih terbatas. Pada masyarakat lebih modern pilihan orang tua terhadap pekerjaan anak cenderung rendah, hal ini karena anak memiliki berbagai pilihan pekerjaan dan tingkat pendidikan tinggi. Tetapi pada masyarakat yang sangat modern kembali pengaruh orang tua terhadap pilihan pekerjaan anak besar atau kuat, karena saingan untuk mendapatkan pekerjaaan semakin banyak. ${ }^{6}$

${ }^{1}$ M Dofier Damopoli., Pesantren Modern IMMIM Pencetak Muslim Modern,( Jakarta: PT Rajagrafindo Persada, 2011) 157.

${ }^{2}$ Mulyani, L., Peran Pondok Pesantren Dalam Membina Perilaku Santri Yang Berwatak Terpelajar Dan Islami: Studi Deskriptif Di Pesantren Al-Basyariah Desa Rahayu Kecamatan Margaasih Kabupaten Bandung,( Doctoral Disserta-tion, Universitas Pendidikan Indonesia, 2012) 11.

${ }^{3}$ Sujoko.P, Profil Pesantren; Laporan Hasil Penelitian Pesantren al Falak dan Delapan Pesantren Lain di Bogor ( Jakarta: LP3ES, 1982) 7.

${ }^{4}$ Damopoli, Pesantren Modern IMMIM Pencetak Muslim Modern, 65.

${ }^{5}$ Husni Rahim, Arah Baru Pendidikan Islam Indonesia (Jakarta: Logos Wacana Ilmu, 2011), 190-191

${ }^{6}$ Zamroni. Sosiologi Modernisasi. (Yogyakarta: Tiara Wacana, 1998), 125. 
Pesantren harus mampu menyiapkan sumber daya dan sumber dana untuk membangun fasilitas yang mencukupi kegiatan operasional pesantren, agar pesantren dapat berperan total menjadi sebuah lembaga pendidikan bagi masyarakat baik dari segi keilmuan agama maupun pendidikan formal. Sebab hal ini sebagaimana dijelaskan oleh Nanang Fatah (2002, hlm.89) sebagai berikut : Upaya perluasan dan persebaran kesempatan bagi anak-anak untuk memperoleh pendidikan, khususnya pendidikan dasar menempati prioritas tertinggi dalam perkembangan pendidikan nasional. Sejalan dengan derasnya arus perubahan sosial akibat modernisasiindustrialisasi mau tidak mau menuntut pesantren untuk memberikan reaksi atau respons secara memadai. Reaksi pesantren menghadapi perubahan yang berjalan selama ini ada yang lunak dan ada yang keras. Ada yang membuka dan ada yang menutup diri. Namun meski ada yang mendefinisikan zaman sekarang sebagai zaman edan atau jahiliyah modern, ternyata tidak sedikit yang mencoba melakukan transformasi dengan melakukan mobilitas budaya yang menyebabkan doktrin, lembaga dan pranata sosial menjadi tetap relevan.

Selain itu, pesantren juga selalu dituntut untuk melakukan adjustment and readjustment ${ }^{7}$ mulai dari melakukan diversifikasi program dengan membuat yayasan, memasukkan sistem sekolah, kontekstualisasi kitab kuning, memodernisasi manajemen pengelolaan, reorientasi fungsi dengan memasukkan fungsi sosial ekonomi ke dalam program pesantren dan lain-lain. Bersamaan dengan kemajuan ilmu pengetahuan dan teknologi, timbul beberapa kecenderungan masyarakat dalam melihat posisi, fungsi, dan peran pesantren. Di satu sisi, ada yang menilai pesantren merupakan lembaga pendidikan yang hanya mampu mencetak alumni yang memiliki kemampuan agama tanpa kemampuan yang dibutuhkan pasar, khususnya tenaga kerja. Pandangan seperti ini, menjadikan pesantren sebagai lembaga pendidikan 'pelarian'. Dalam menyikapi pandangan seperti ini, telah banyak pesantren yang memberikan bekal ketrampilan terhadap para santrinya. Pesantren tidak hanya membekali para santri dengan ilmu-ilmu keislaman tetapi telah memberikan ketrampilan yang bersifat aplikatif dan siap kerja. ${ }^{8}$

Tuntutan dan kebutuhan masyarakat juga berdampak terhadap eksistensi pesantren saat ini. Persepsi masyarakat yang masih kuat di seputar 'dunia kerja' menjadikan keberadaan suatu pesantren terancam. Kurangnya civil effect yang dimiliki pesantren merupakan persoalan tersendiri. Kebanyakan orang tua menginginkan anakanaknya kelak setelah menyelesaikan studi akan mendapatkan pekerjaan dan bisa melanjutkan studi. Persoalan seperti ini masih membayangi pesantren, khususnya yang masih mempertahankan ciri khas 'kesalafiyahan'nya dengan sajian pelajaran agama yang lebih dominan karena pesantren merupakan cerminan dari dunia tradisional Islam. ${ }^{9}$

Hal lain yang hingga kini masih dimiliki pesantren adalah penekanannya pada nilai-nilai yang dianutnya, seperti kemandirian, kesederhanaan, dan keikhlasan. Nilai-nilai dasar ini dibingkai dengan paradigma yang sangat menekankan kepada apresiasi terhadap segala tradisi yang baik sekaligus akomodatif terhadap bentuk-bentuk reformasi yang dapat dipertanggung jawabkan. Nilainilai yang cukup kental di dunia pesantren ini pada prinsipnya merupakan nilainilai keagamaan yang otentik yang memiliki benang merah kuat dengan kesejarahan umat dan normativitas Islam hakiki. Hasil dari semua itu adalah kehadiran pesantren sebagai institusi yang mampu memberikan sumbangan penting dan krusial dalam proses transmisi ilmu-ilmu Islam, reproduksi ulama, pemeliharaan ilmu dan tradisi Islam, bahkan pembentukan dan ekspansi masyarakat Muslim Santri

Kenyataan itu telah membuat lembaga tersebut memiliki keunggulan yang cukup signifikan. Padahal jika kita melihat potensi dan perkembangan pesantren sekarang ini sebagaimana yang di katakan oleh Azyumardi Azra pesantren sekarang diharapkan tidak lagi sekedar memainkan fungsi

\footnotetext{
${ }^{7}$ Azyumardi Azra, Pendidikan Islam, Tradisi dan Modernisasi Menuju Millenium Baru (Jakarta: Logos Wacana Ilmu, 1999), h. 108

${ }^{8}$ Mujamil Qamar, Pesantren: Dari Transformasi Metodologi Menuju Demokratisasi Institusi (Jakarta:: Airlangga, 2007), 79.

9 Amin Haidari, dkk., Masa Depan Pesantren dalam Tantangan Modernitas dan Tantangan Kompleksitas Global, (Jakarta:: IRD Press, 2004) 193-194.
} 
tradisionalnya yaitu; "transmisi dan transfer ilmu-ilmu Islam, pemeliharaan tradisi Islam, reproduksi ulama", tetapi juga menjadi pusat penyuluhan kesehatan, pusat pengembangan teknologi tepat guna bagi masyarakat pedesaan, pusat usaha-usaha penyelamatan dan pelestarian lingkungan hidup; dan lebih penting lagi menjadi pusat pemberdayaan ekonomi masyarakat dan sekitarnya. ${ }^{10}$ Maka dari itulah fungsi pesantren tidak hanya sebagai pusat pengkaderan pemikir-pemikir agama (center of exellence), sebagai lembaga yang mencetak sumber daya manusia (human resource), tetapi juga diharapkan menjadi lembaga yang dapat melakukan pemberdayaan pada masyarakat (agent of development).. Melihat fungsi yang dimilikinya sebenarnya pesantren dapat berperan sebagai lembaga perantara yang diharapkan dapat menjadi dinamisator dan katalisator pemberdayaan sumberdaya daya manusia, penggerak pembangunan di segala bidang, termasuk di bidang ekonomi.

\section{Aspek Ekonomi Dalam Pengelolaan Dan Pengembangan Pesantren}

Selain membantu upaya pemerintah dalam bidang pendidikan, pesantren dalam beberapa tahun terakhir ini mulai banyak mengembangkan usaha dan bisnisnya sebagai salah satu cara untuk merawat dan mempertahankan eksistensi pesantren di tengah masyarakat.

Dari segi ekonomi dan sosial, pendidikan suatu negara adalah alat penting untuk melestarikan norma dan meningkatkan keterampilan masyarakat secara berkelanjutan dan mempersiapkan masyarakat tadi bagi kebutuhan pembangunan yang sedang berlangsung. Dengan kekuatan yang dimilikinya, pesantren mempunyai potensi untuk melakukan pemberdayaan umat terutama dalam bidang ekonomi. Karena melakukan pemberdayaan ekonomi merupakan bentuk dakwah bil hal dan sekaligus mengimplementasikan ilmu-ilmu yang dimilikinya secara kongkrit (aplikatif). ${ }^{11}$

Sejalan dengan itu, Islam sangat memperhatikan permasalahan ekonomi yang merupakan bagian dari permasalahan umat yang tentu memiliki tujan yang sama yakni tercapainya maslahah di dunia dan akhirat. Di samping mengamalkan nilai-nilai spiritual dan akhlakul karimah, Islam juga mewajibkan umatnya untuk berkecukupan secara material. Menurut Umer Chapra, keselarasan kesejahteraan individu dan kesejahteran masyarakat yang senantiasa menjadi konsensus ekonomi Islam dapat terealisasi jika dua hal pokok terjamin keberadaannya dalam kehidupan setiap manusia, yaitu pelaksanaan nilai-nilai spiritual Islam secara keseluruhan untuk individu maupun masyarakat dan pemenuhan kebutuhan pokok material manusia dengan cukup.

Al-Qur'an juga yang menjelaskan kaitannya dengan penguatan ekonomi umat untuk bekerja keras dan mengajarkan pentingnya umat Islam untuk bekerja dan memikirkan ekonominya. Di antaranya QS. Al-Qashash [28]: 77: "Carilah pada apa yang telah dianugerahkan Allah kepadamu [kebahagiaan] negeri akhirat; dan janganlah kamu melupakan bagianmu dari [kenikmatan] duniawi. Berbuat baiklah [kepada orang lain] sebagaimana Allah telah berbuat baik kepadamu. Janganlah kamu berbuat kerusakan di bumi”. Berpangkal dari keberadaan manusia sebagai obyek ekonomi (produsen dan juga konsumen) maka kecuali upaya pembenahan sistem ekonomi, seperti peningkatan partisipasi modal swasta, hal yang tak kalah pentingnya adalah menggarap ketrampilan dan daya kemampuan pelaku ekonomi, yang berkaitan dengan usaha atau ikhtiar manusia. ${ }^{12}$

Menyinggung perihal ikhtiar dalam perekonomian, kita ingat sebuah hadits yang kurang lebih artinya, "Bekerja untuk memenuhi kebutuhan ekonomi adalah wajib (fardhu) setelah kewajiban yang lain." Interpretasi hadits ini akan melahirkan kelompok-kelompok manusia produktif atau manusia yang bersumber daya tinggi yang sekaligus merupakan inti perekonomian. Barangkali dari kenyataan bahwa Allah tidak memberi rizqi dalam bentuk jadi dan siap digunakan, melainkan hanya dipersiapkan sebagai sarana dan sumber daya alam, maka sudah barang tentu untuk mengolahnya, mengikhtiari dalam bentuk industri, dan lain-lain. Dari hadits ini, kita bisa menemukan pandangan yang proporsional terhadap ekonomi.

Beberapa dasar mengenai penguatan ekonomi itulah yang dapat dijadikan pedoman oleh pesantren untuk membekali para santrinya dengan berbagai ketrampilan/ keahlian di bidang ekonomi seperti koperasi, kerajinan dan berdagang. Semua itu dilakukan oleh pihak pesantren

\footnotetext{
${ }^{10}$ Azyumardi Azra, Jaringan Ulama (Bandung: Mizan, 1997) 22.

${ }^{11}$ Jusuf Enoch, Dasar-dasar Perencanaan Pendidikan ( Jakarta : Bumi Aksara, 1992) 167.

12 Sahal Mahfudz, Nuansa Fiqh Sosial ( Yogyakarta: LKiS, 1994) 151.
} 
sebagai upaya untuk membekali para santri dengan berbagai skill keahlian atau setidaknya menyiapkan mental dan ketrampilan para santri supaya kelak ketika keluar dari pesantren sudah bisa mandiri. Ada beberapa pesantren yang mencoba membuat satu ikhtiar menambah kemampuan santri di bidang wira usaha atau ekonomi. Berangkat dari kesadaran bahwa tidak semua santri akan menjadi ulama, maka beberapa pesantren mencoba membekali santri dengan ketrampilan di bidang pengembangan ekonomi. Artinya santri yang dihasilkan diharapkan mempunyai pengalaman dan syukur keahlian praktis tertentu yang nantinya dijadikan modal untuk mencari pendapatan hidup sekeluar dari pesantren.

Mencermati perilaku ekonomi di lingkungan pesantren pada umumnya, kita dapat menerka kemungkinan model apa yang sedang berjalan dalam usaha usaha tersebut. Setidaknya ada empat macam kemungkinan pola usaha ekonomi di lingkungan pesantren; Pertama, usaha ekonomi yang berpusat pada kyai sebagai orang yang paling bertanggungjawab dalam mengembangkan pesantren. Misalnya seorang kyai mempunyai perkebunan cengkih yang luas. Untuk pemeliharaan dan pemanenan, kyai melibatkan santri-santrinya untuk mengerjakannya. Maka terjadilah hubungan mutualisme saling menguntungkan: kyai dapat memproduksikan perkebunannya, santri mempunyai pendapatan tambahan, dan ujungnya dengan keuntungan yang dihasilkan dari perkebunan cengkeh maka kyai dapat menghidupi kebutuhan pengembangan pesantrennya, seperti kasus di Pandeglang, yaitu pesantren Nurul Hidayah Cilaja kec. Pandeglang. ${ }^{13}$ Kedua, usaha ekonomi pesantren untuk memperkuat biaya operasional pesantren. Contohnya, pesantren memiliki unit usaha produktif seperti menyewakan gedung pertemuan, rumah dsb. Dari keuntungan usaha-usaha produktif ini pesantren mampu membiayai dirinya, sehingga seluruh biaya operasional pesantren dapat ditalangi oleh usaha ekonomi ini, seperti pesantren Wali Songo Ngabar yang mempunyai beberapa usaha seperti mini market, sawah, ternak kambing dan sapi, yang hasilnya untuk pembiayaan pesantren. Ketiga, usaha ekonomi untuk santri dengan memberi ketrampilan dan kemampuan bagi santri agar kelak ketrampilan itu dapat dimanfaatkan selepas keluar dari pesantren. Pesantren membuat program pendidikan sedemikian rupa yang berkaitan dengan usaha ekonomi seperti pertanian dan peternakan. Tujuannya semata-mata untuk membekali santri agar mempunyai ketrampilan tambahan, dengan harapan menjadi bekal dan alat untuk mencari pendapatan hidup. Pesantren Baitul Hamdi di Menes Pandeglang dapat dijadikan sampel pesantren dalam jenis ini juga, karena disana santri diajak untuk bertani, dan berkebun. Keempat, usaha ekonomi bagi para alumni santri. Pengurus pesantren dengan melibatkan para alumni santri menggalang sebuah usaha tertentu dengan tujuan untuk menggagas suatu usaha produktif bagi individu alumni, apabila nanti keuntungan selebihnya dapat digunakan untuk mengembangkan pesantren. Prioritas utama tetap untuk pemberdayaan para alumni santri. Hal ini seperti yang dilakukan oleh pesantren Sidogiri Pasuruan Jawa Timur dan pesantren Maslakul Huda di Kajen Pati Jawa Tengah.

\section{Peran Masyarakat Sekitar Dalam Pengelolaan Dan Pengembangan Ekonomi Pesantren}

Pesantren secara historis didirikan dari dan untuk masyarakat. Pesantren didirikan dengan tujuan mengadakan transformasi sosial bagi masyarakat daerah sekitarnya. Ia hadir mengabdikan dirinya mengembangkan dakwah Islam dalam pengertian luas, mengembangkan masyarakat sesuai dengan nilai-nilai keagamaan dan pada gilirannya didukung secara penuh oleh mereka. Signifikansi pelibatan pesantren dalam pemberdayaan masyarakat, berpeluang pada kenyataan bahwa masyarakat Indonesia yang mayoritas terdiri dari komunitas muslim pada umumnya berada di daerah pedesaan. Pada sisi itu, pesantren yang memang berkembang dan tersebar di daerah-daerah pedesaan sampai derajat tertentu, merupakan representasi dari masyarakat muslim daerah-daerah pedesaan. Kenyataan itulah yang membuat pesantren sampai saat ini masih berpengaruh pada hampir seluruh aspek kehidupan di kalangan masyarakat muslim pedesaan yang taat.

Tetapi upaya untuk menuju ke arah pemberdayaan masyarakat melalui fungsi ekonomi pesantren terkadang dibenturkan dengan berbagai kenyataan yang bisa menjadi penghambat

13 Ali Murtadlo, Pesantren dan Pemberdayaan ekonomi (Studi Kasus Pesantren Baitul Hamdi dan Pesantren Turus di Pandeglang) Di akses dari www.bappenas.go.id. Dikutip pada 20 mei 2011, 6. 
langkah tersebut. Salah satu contohnya adalah karena biasanya pesantren selalu menjadi tempat bagi keluarga dekat kiai, yang bisa berupa anak, cucu dan seterusnya atau biasa disebut dzurriyyah kiai. Mereka kadang bertumpu secara ekonomis terhadap santri, apakah dalam bentuk penyediaan makanan, bahan kebutuhan sehari-hari, atau yang lainnya. Di banyak pesantren selalu terdapat kioskios kecil milik keluarga kiai yang terkadang menjadi tumpuan ekonomi keluarga. Inilah sulitnya ketika pesantren kemudian mencoba untuk memusatkan kegiatan ekonomi dalam satu lembaga. Kegagalan koperasi Pondok pesantren pada dasarnya adalah karena usaha itu dihadang oleh kepentingan-kepentingan internal. Selain itu harus diakui bahwa manajemen ekonomi pesantren juga relatif kurang baik, bukan dari aspek kejujurannya tapi administrasinya. ${ }^{14}$

Selain itu kekurangan juga kerap tumbuh pada persoalan yang bersifat paradigmatik. Satu contoh misalnya nilai-nilai kemandirian yang dianut pesantren masih lebih menampakkan aspeknya yang bersifat individual, atau sangat lokal dan belum menjadi sikap sosial kemasyarakatan yang transformatif. Persoalan itu ditambah dengan pemaknaan sebagian pesantren terhadap pengabdian dan pengembangan masyarakat yang masih terkesan parsial dan melulu ditekankan pada aspek pengembangan keilmuan keagamaan murni. Sebagai konsekuensi pelibatan masyarakat dalam penguatan ekonomi di kalangan pesantren belum disentuh secara kreatif dan serius dalam bentuk penyatuan yang integral dan eksplisit ke dalam kurikulum yang dikembangkan pesantren. Tradisi itu tidak cukup dalam dirinya sendiri untuk memetamorfosis sebagai nilai civil society yang berkeadaban, universal dan berorientasi jauh ke depan.

Untuk menambal kekurangan tersebut, maka yang harus diperhatikan dalam penguatan kelembagaan itu antara lain adalah, pertama, menganalisis kebutuhan subjek sasaran ekonomi atau yang disebut sebagai need-assessment. Analisis kebutuhan diperlukan agar apa yang akan dipasarkan itu memang menjadi kebutuhan sasaran. Pada tahap awal tentunya harus dibidik kebuthan-kebutuhan santri dan masyarakat sekitar, agar produk yang ditawarkan akan segera diperoleh nilai imbal balik. Baru bisa bergerak ke sektor yang lain, jika kondisi memang sudah memungkinkan. Kedua, melakukan analisis potensi SDM untuk kegiatan (ekonomi) tersebut. Apakah sudah ada SDM yang bisa dan mampu untuk menjadi agen bagi pengembangan kelembagaan ekonomi pesantren tersebut? Pesantren sesungguhnya kaya dengan SDM yang berkualitas, hanya saja belum disentuh dengan kekuatan maksimal untuk itu. Ketiga, memetakan kebutuhan dan potensi untuk dijadikan sebagai rancangan program yang memadai. Keempat, melaksanakan program dengan memperhatikan jaringan kerja atau networking yang telah dimiliki oleh pesantren. Kelima, melakukan evaluasi kinerja apakah sudah ada kemajuan atau belum.

Pelibatan masyarakat untuk menguatkan ekonomi pesantren, setidaknya ada tiga motif yang dimiliki oleh peantren, Pertama, motif keagamaan, karena kemiskinan bertentangan dengan etika sosial ekonomi Islam. Kedua, motif sosial, karena kyai juga seorang pemimpin yang harus mengatasi krisis ekonomi setempat. Ketiga, motif politik, karena pemegang kekuasaan setempat mempunyai kepentingan-kepentingan pribadi pada tingkat mikro dan makro. Pondok pesantren dalam fungsinya melayani masyarakat, dapat pula dilihat dari upayanya dalam melayani masyarakat, terutama kebutuhan untuk menanggapi persoalan-persoalan kemiskinan, memberantas kebodohan, menciptakan kehidupan yang sehat dan sebagainya.). Di sinilah bisa ditunjukkan betapa pentingnya kehadiran pesantren yang tidak hanya mementingkan kepentingan sendiri tetapi juga kepentingan masyarakat sekitar lebih mendapat tempat dalam kerangka usaha meningkatkan kesejahteraan masyarakat baik lahir maupun batin. ${ }^{15}$

\section{E. Cita-Cita Kemandirian Ekonomi Pesantren}

Istilah kemandirian dapat diartikan dengan hal atau keadaan seseorang dapat berdiri sendiri atau tidak bergantung kepada orang lain. Kemandirian berasal dari kata "diri", yang berarti ia tidak dapat dilepaskan dari perkembangan diri seorang individu. Diri adalah inti dari kepribadian dan

${ }^{14}$ Usman, Sunyoto, Pembangunan dan Pemberdayaan Masyarakat, Yogyakarta: Pustaka Pelajar, 2003, Hal : 38

15 Achmad Zaini, Kiai Haji Abdul Wahid Hasyim His Contribution to Muslim Education, ( Yogyakarta: Titian Ilahi Press, 1998), 126. 
merupakan titik pusat yang menyelaraskan dan mengkoordinasikan seluruh aspek kepribadian. Dengan kata lain, kemandirian adalah kesiapan dan kemampuan individu untuk berdiri sendiri yang ditandai dengan keberanian mengambil inisiatif, mencoba mengatasi masalah tanpa minta bantuan orang lain, berusaha dan mengarahkan tingkah laku menuju kesempurnaan. ${ }^{16}$

Kemandirian bukan berarti menyediri atau serba sendiri. Seorang yang mandiri adalah seseorang yang berhasil membangun nilai dirinya sedemikian sehingga mampu menempatkan perannya dalam alam kehidupan kemanusiaannya dengan penuh manfaat. Kemandirian adalah tidak adanya rasa takut. Bila ada kemandirian, berarti tidak akan ada keharusan, tidak akan ada tuntutan, dan tidak akan ada kebergantungan. ${ }^{17}$

Sedangkan Ekonomi berdasarkan Kamus Besar Bahasa Indonesia adalah ilmu mengenai asasasas produksi, distribusi, dan pemakaian barang-barang serta kekayaan (seperti keuangan, perindustrian, dan perdagangan). ${ }^{18}$

Jadi kemandirian ekonomi adalah sebuah proses perbaikan, penguatan, dan penyempurnaan terhadap semua kemampuan dan potensi dalam bidang ekonomi sehingga mencapai kemandirian dan kesejahteraan baik finansial maupun spiritual.

Telah ada beberapa penelitian yang membahas tentang kemandirian pesantren. Studi yang dilakukan oleh Syahid Ismail menyatakan bahwa program kemandirian yang dikembangkan oleh pesantren hari ini sebagai bagian dari tuntutan pendidikan, ekonomi dan dakwah pesantren itu sendiri, dampak positif kegiatan perkonomin pesantren dirasakan oleh seluruh warga di dalam pesantren maupun warga sekitar pesantren. ${ }^{19}$ Penelitian terkait kemandirian pesantren yang dilakukan oleh Muchlis Solichin menyatakan bahwa proses kemandiri yang dilakukan oleh pesantren melalui kegiatan-kegiatan perekonomian yang dijalankan pesantren berorientasi pada, pertama, pandangan Pengasuh Pondok Pesantren tentang kemandirian adalah tiadanya ketergantungan pesantren dengan pihak ekternal dalam berbagai aktivitasnya. Kedua, Pondok Pesantren mempertahankan kemandiriannya dengan upaya-upaya, yaitu secara sosial politik; berupaya tetap berada di atas semua golongan dan kekuatan sosial politik di luar pesantren; upaya secara ekonomi dengan mengembangkan berbagai badan usaha yang dengannya dapat membiayai kegiatan pendidikannya. ${ }^{20}$

Dari penelitian di atas jelaslah bahwa pesantren hari ini selain harus bisa menjadi agent of change di masyarakat juga harus bisa menganalisis isu-isu strategis yang kaitannya dengan tren-tren baru pengembangan pondok pesantren. Pesantren juga harus membangun kemandirian pondok pesantren melalui kegiatan-kegiatan produktif pondok pesantren yang kelak bisa menjadi sumber penghasilan bagi pengembangan pesantren dan kedepannya pesantren bisa leluasa mengembangkan diri tanpa takut 'mandeg' di tengan perjalanan jika kekurangan atau kehilangan sumber pendanaan dari pemerintah atau masyarakat. Untuk itu pesantren harus mampu menciptakan kemandirian yang tidak bergantung kepada donatur saja melainkan juga harus mengembangkan kreatifitas.

\section{F. Upaya Mewujudkan Ekonomi Kreatif Partisipatif Untuk Menopang Kemandirian Pesantren}

Pada dasarnya secara kuantitas, potensi dukungan masyarakat luas terhadap dana pendidikan pesantren sangatlah besar, dengan populasi penduduk Indonesia yang berjumlah kurang lebih 210 juta, $85 \%$ adalah umat Islam, yang berarti 178,5 juta orang. Dalam kenyataannya potensi ini belum

16 Tim Penulis Rumah Kitab, Pendidikan Karakter Berbasis Tradisi Pesantren (Jakarta: Rumah Kitab, 2014),211

${ }^{17}$ Agung Webe. 7 Langkah Sederhana Untuk Mengubah Hidup Menjadi Lebih Bermakna. ( Jakarta:PT Elex Media Komputendo, 2009) 51.

${ }^{18}$ Tim Penyusun Kamus Pusat Bahasa. Kamus Besar Bahasa Indonesia. Pusat Bahasa Edisi Keempat. (Jakarta: Pusat Bahasa 2009) 377.

${ }^{19}$ Ismail Syahid, "Strategi Mewujudkan Kemdnirian Pondok Pesantren Berbasis Pemberdayaan Santri (studi kasus pesantren Hidayatullah Desa Bandar Labuan, Kecamatan Tanjung Morawa, Kabupaten Deli Serdang), ” Jurnal Perspektif Sosiologi, 4 (1) Januari 2016: 56

${ }^{20}$ Mohammad Muchlis Solichin, "Kemandirian Pesantren di Era Reformasi”. Nuansa, 9 (1) Januari - Juni 2012: 187 
tergali dengan baik sehingga kurang memberikan dampak bagi pendidikan pesantren. Maka sudah saatnya kini pesantren lebih bisa memanfaatkan potensi dan kreasi secara lebih baik.

Menurut Chusnul Chotimah dalam studi kasusnya di Pondok Pesantren Sidogiri Pasuruan, bahwa kemandirian ekonomi di pondok pesantren Sidogiri dimulai dari internalisasi nilai-nilai intangibles kepada santri, sehingga jiwa santri tergerak melakukan yang terbaik untuk pondok pesantren. Untuk selanjutnya, bagaimana sebuah pesantren dapat mencapai kemandirian dalam bidang perekonomian, dapat dimulai dengan berbagai langkah berikut; Pertama, sosialisasi jiwa kemandirian. Pimpinan pesantren membekali jiwa kemandirian pada santri agar mereka mampu menciptakan sebuah ide-ide kewirausahaan demi mencapai perekonomian yang lebih baik. Pesantren memiliki sumber daya manusia yang cukup memadai untuk mengelola sebuah usaha yang nantinya keuntungannya dapat digunakan untuk mendukung biaya pendidikan yayasan pesantren; Kedua, Mengubah Mental. Tidak semua pesantren dapat berkembang baik dalam hal kemandirian ekonomi. Namun sejatinya, pesantren memiliki peluang untuk menciptakan kemandirian. Bagaimana sebuah pesantren dapat merubah mental lemah dan pemikiran terbelakang menjadi sebuah mental kuat yang selalu berpikir kreatif demi kemajuan pesantren; Ketiga, jemput bola. Pesantren sendiri tentunya harus memiliki inisiatif dalam mencapai kesuksesan yakni "menjemput bola". Tidak menunggu saja rezeki itu datang, menjemput rezeki dengan menciptakan dan merealisasikan ide-ide cemerlang; Keempat, Mampu bertahan. Pesantren demi mempertahankan diri, juga perlu mempertahankan tempat yang konsisten dalam wujud nyata dengan cara membentuk sebuah legalitas dan menyebarluaskannya sebagai salah satu cara untuk mengembangkan eksistensi pesantren. Legalitas nama dan penyebarluasan ini dapat digunakan untuk menggaet donatur, baik donatur dari masyarakat maupun dari pemerintah.

Selain langkah-langkah di atas, untuk mempertahankan kemandirian, sebuah pesantren memiliki sumber pendanaan yang dapat dikelola dengan baik. Contohnya membangun koperasi pesantren yang menyediakan barang-barang dan kebutuhan santri sehari-hari. Koperasi pesantren dapat dikelola oleh santri yang keuntungannya untuk pesantren. Dalam hal ini, pesantren melatih santri untuk berdagang. Selain itu juga dengan menciptakan sumber-sumber ekonomi lainnya dengan melihat letak geografis pesantren. Meninjau berbagai pesantren pada umumnya di Jawa Timur, beberapa usaha perekonomian pesantren adalah peternakan, perkebunan, dan usaha air minum. Sumber ekonomi ini dapat bekerja sama dengan mitra usaha lain atau dapat berdiri sendiri yang berawal dari modal nilai kemandirian.

Langkah-langkah strategis untuk mewujudkan mitra usaha di pesantren dapat dimulai sebagai berikut: Langkah pertama, mencari konseptor/ donator. Dalam hal ini ide usaha pesantren harus jelas dan memiliki konsep yang matang. Jika sebuah ide usaha tersebut menarik tentu para donatur tidak akan segan untuk mendonasikan hartanya dalam mendukung usaha tersebut. Langkah kedua, pemberdayaan industri yang cocok untuk pesantren. Hal ini sangat dipengaruhi oleh letak geografis dan potensi lokal yang ada di lingkungan pesantren. Seperti halnya yang telah dilakukan oleh beberapa pesantren dengan mendirikan BMT, usaha air minum, budidaya ternak lele, budidaya ternak ayam, dan masih banyak lagi usaha-usaha yyang berbasis letak geografis dan potensi lokal. Pemberdayaan industri di sekitar lingkungan pesantren dapat dijadikan mitra usaha pesantren dalam mengembangkan perekonomian. Pimpinan pesantren bernegosiasi dengan pimpinan industri sehingga para alumnus pesantren yang memiliki skill dalam bidangnya mampu menembus industri. Langkah ketiga, pengelolaan saham ternak menjadi saham yang besar. Langkah ini memiliki kompleksitas dan kendala yang besar. Ada beberapa pesantren yang memiliki budidaya ternak, namun tidak semuanya dapat berkembang secara meluas. Untuk mewujudkannya, pengeloaan budidaya ternak di pesantren perlulah membangun mitra usaha dengan usaha peternakan lain di luar pesantren agar memperoleh saham yang besar.

Usaha mandiri yang dijalankan oleh pesantren baik itu pertanian, peternakan, perikanan, dan lainnya tentunya memberikan dampak yang baik bagi pesantren, kondisi ini mendorong pesantren pada sebuah kondisi yang mana pesantren mejadi lembaga yang mandiri tidak sepenuhnya bergantung pada pendanaan dari pemerintah maupun masyarakat. 


\section{Daftar Pustaka}

Achmad Zaini, 1998, Kiai Haji Abdul Wahid Hasyim: His Contribution to Muslim Education, Yogyakarta, Titian Ilahi Press.

Agung Webe, 2009, 7 Langkah Sederhana Untuk Mengubah Hidup Menjadi Lebih Bermakna, PT Elex Media Komputendo.

Ali Murtadlo, 2011, Pesantren dan Pemberdayaan ekonomi ((Studi Kasus Pesantren Baitul Hamdi dan Pesantren Turus di Pandeglang), Di akses dari www.bappenas.go.id. Dikutip pada 20 mei 2011.

Amin Haidari, dkk., 2004, Masa Depan Pesantren dalam Tantangan Modernitas dan Tantangan Kompleksitas Global, Jakarta, IRD Press.

Azyumardi Azra, 1997, Jaringan Ulama, Bandung, Mizan.

Damopolii,M., 2011, Pesantren Modern IMMIM Pencetak Muslim Modern, Jakarta, PT Rajagrafindo Persada.

Husni Rahim, 2011, Arah Baru Pendidikan Islam Indonesia. Jakarta, Logos Wacana Ilmu.

Ismail Syahid, 2016, Strategi Mewujudkan Kemdnirian Pondok Pesantren Berbasis Pemberdayaan Santri (studi kasus pesantren Hidayatullah Desa Bandar Labuan, Kecamatan Tanjung Morawa, Kabupaten Deli Serdang), Jurnal Perspektif Sosiologi, 4 (1) Januari 2016.

Jusuf Enoch, 1992, Dasar-dasar Perencanaan Pendidikan, Jakarta. Bumi Aksara.

M. Dawam Raharjo, 1988, Pesantren dan Pembaharuan, Cet. IV; Jakarta, LP3ES.

M. Nadzir, 2016, Economica: Jurnal Ekonomi Islam, vol. 6, issue 1 ,Published by UIN Walisongo Semarang.

Mohammad Muchlis Solichin, 2012, Kemandirian Pesantren di Era Reformasi, Nuansa, 9 (1) Januari - Juni 2012.

Mujamil Qamar, 2007, Pesantren: Dari Transformasi Metodologi Menuju Demokratisasi Institusi, Jakarta, Airlangga.

Mulyani, L., 2012, Peran Pondok Pesantren Dalam Membina Perilaku Santri Yang Berwatak Terpelajar Dan Islami: Studi Deskriptif Di Pesantren Al-Basyariah Desa Rahayu Kecamatan Margaasih Kabupaten Bandung, Doctoral Disserta-tion, Universitas Pendidikan Indonesia.

Nanang Fattah, 2002, Ekonomi dan pembiayaan Pendidikan, Jakarta, Rosdakarya.

PP no. 55/2007 dan PMA no. 13/2014 tentang pesantren sebagai lembaga pendidikan keagamaan Islam.

Sahal Mahfudz, 1994, Nuansa Fiqh Sosial, Yogyakarta, LKiS.

Sujoko.P, 1982, Profil Pesantren; Laporan Hasil Penelitian Pesantren al Falak dan Delapan Pesantren Lain di Bogor, Jakarta, LP3ES.

Sunyoto Usman, 2003, Pembangunan dan Pemberdayaan Masyarakat, Yogyakarta, Pustaka Pelajar.

Tim Penulis Rumah Kitab, 2014, Pendidikan Karakter Berbasis Tradisi Pesantren, Jakarta: Rumah Kitab.

Tim Penyusun Kamus Pusat Bahasa, 2008, Kamus Besar Bahasa Indonesia, Pusat Bahasa Edisi Keempat, Jakarta, Pusat Bahasa.

Undang -Undang Nomor 20 Tahun 2003 tentang Sistem Pendidikan Nasional

Zamroni. 1998, Sosiologi Modernisasi. Yogyakarta, Tiara Wacana. 